\title{
Assessment of the Rule of Intubation on the Outcome of External Dacryocystorhinostomy
}

\author{
AIMAN A. HASHISH, M.D.; OSAMA E. SHALABY, M.D.; MOLHAM A. EL-BAKARY, M.D. and \\ OMAR M. MASSOUD, M.Sc.
}

The Department Opthalmology, Faculty of Medicine, Tanta University

\begin{abstract}
Background: Dacryocystorhinostomy (DCR) surgery through an external approach has been the gold standard for the treatment of nasolacrimal duct obstruction. The question whether to use silicone tube or not.

Aim of Study: The aim of this study was to evaluate the rule of bicanalicular intubation in the success rate of external DCR. This study was to evaluate the effect of intubation on the outcome of external dacryocystorhinostomy.

Patients and Methods: It was a prospective interventional randomized study that was carried on 45 eyes of patients had done DCR. All operations were done under general anathesia and they were divided into 3 groups as follow:

1- Group (A): 15 patient had done DCR with long term intubation (12 weeks).

2- Group (B): 15 patient had done DCR with short term intubation ( 2 weeks).

3- Group (C): 15 patient had done DCR with no intubation.

Results: There is no significant difference between the use of intubation or not in cases of acquired NLDO and chronic dacryosistitis.

Conclusion: External dacryocystorhinostomy is still the gold standard surgical treatment in primary nasolacrimal duct obstruction. This study shows that the silicone tube implantation is not necessary in the surgery.
\end{abstract}

Key Words: Dacryocystorhinostomy (DCR).

\section{Introduction}

NORMAL drainage of tear from the conjunctival sac into the nose is dependent on patency of the nasolacrimal passage that includes the lacrimal puncta, the lacrimal canaliculi, the common canaliculus, the lacrimal sac and the nasolacrimal duct, which opens into the inferior meatus of the nose [1]. Blockage of any portion of this passage by

Correspondence to: Dr. Aiman A. Hashish, The Department Opthalmology, Faculty of Medicine, Tanta University inflammation, scarring, trauma, stone or neoplasm results in epiphora [2].

Since 1904 dacryocystorhinostomy (DCR) surgery through an external approach has been the gold standard for the treatment of nasolacrimal duct obstruction [3]. This operation is designed to drain the tears and the infected secretion from lacrimal sac into the nose through an ostium in the lacrimal bone and the nasal mucosa [4] .

Intubation of the lacrimal drainage system with silicone tubes, introduced by Quickert \& Dryden (1970) [5], represented a major refining step in lacrimal surgery. Because the most common causes of failed DCR involve common canaliculus or osteotomy site obstructions, it is generally assumed that the use of silicone tubes in DCR may prevent these obstructions, and thus improve surgical results [6]. Moreover, many reports concerning simultaneous silicone intubation in DCR have concluded that it is a safe and effective procedure for canalicular or nasolacrimal duct disorders [7].

However, many complications have been attributed to silicone tube placement and it was recently suggested that silicone intubation during DCR may actually increase the risk of failure [8] .

\section{Patients and Methods}

It was a prospective interventional randomized study that was carried on 45 eyes of 45 patients presented to Tanta University Eye Hospital from Sep. 2013 - Dec. 2018 in need for DCR operation.

\section{Inclusion criteria:}

All cases submitted for DCR:

1- Chronic dacryocystitis.

2- Aquired NLD obstruction. 


\section{Exclusion criteria:}

1- Patients with any nasal pathology causing epiphora.

2- Patients with a previous history of DCR.

3- Patients with canalicular pathology.

Complete ophthalmological evaluation was done for all patients:

1- History:

- Personal history: Age, sex, race, occupation.

- Medical history of disease (DM; Hypertension; any diseases that affect wound healing).

- Symptoms:

- Tearing (Epiphora).

- Mucopurulent discharge.

- Mattering of lashes and lids, crusting in the morning.

- Pain.

- Blurred vision from tears.

- Bloody tears.

- Medications used (including sinus decongestants and nasal sprays, topical eye drops).

- Other risk factors (e.g. facial or nasal trauma, sinus disease, environmental allergies, systemic chemotherapeutic drugs, history of sinus or nasal surgery, periorbital radiation).

\section{2- Clinical examination and special tests:}

A careful history was combined with the external examination of the lacrimal system that included an inspection of the face, ocular surface, and eyelid structure including the position and contour of the eyelid and eye blink.

Mass lesion in the medial canthal region is searched for at the region below the medial canthal tendon.

- Eyelid position and lower eyelid tone.

- Slit lamp evaluation of lid margin.

- Regurgitation test.

- Fluroscein dye disappearance test.

- Punctal patency and position.

- Probing \& irrigation.

\section{3- Laboratory investigation:}

\section{1- ENT consultation and evaluation:}

For the nasal mucosa and any abnormal anatomy.

\section{2- Internal medicine consultation:}

For preoperative evaluation by full examination, chest condition, blood pressure and laboratory tests as bleeding profile, Complete blood count and random blood sugar.

All included patients were treated by external DCR and were randomly divided into 3 groups as follow:

- Group (A): 15 patient had long term intubation (12 weeks).

- Group (B) :15 patient had short term intubation (2 weeks).

- Group (C): 15 patient had no intubation.

All patients that were in need for intubation have done intubation by bicanlicular (EAGLE) tube.

The patient rest ed for a few hours after surgery, seated half-reclining to reduce nasal venous congestion, and hot drinks and food are avoided for approximately 12 hours to reduce the chance of epistaxis caused by heat induced nasal vasodilation. The dressing is removed at home on the first postoperative day and a combined topical antibiotic /steroid, (dexamethasone/tobramycin), is used 34 times a day, systemic antibiotic (ciprofloxacin) was used for 1 week, anti-inflamatory, and nasal decongestant for 5 days. The patient is asked to avoid nose blowing for a week. The skin sutures are removed at approximately 1 week and the silicone stent (if were used) 12 weeks in group (A) and at 2 weeks in group (B).

\section{Results}

It was a prospective interventional randomized study that was carried on 45 eyes of patients had done DCR. All operations were done under general anathesia and they were divided into 3 groups as follow:

1- Group (A): 15 patient had done DCR with long term intubation (12 weeks).

2- Group (B): 15 patient had done DCR with short term intubation (2 weeks).

3- Group (C): 15 patient had done DCR with no intubation.

The patients had been examined one week, one month, three months and 6 months post operative.

\section{As regards age distribution:}

The range of age in group (A) was between 2065 years with mean $44.00 \pm 12.9$ while in group (B) the range was between 30-59 years with mean $43.6 \pm 10.1$ and in group $(\mathrm{C})$ it was between 17-53 years with mean $41.3 \pm 11.6$ which indicates that There was no significant difference between the age of the three groups. 


\section{As regards sex distribution:}

The three groups were nearly the same distribution of sex.

There was 6 males $(40 \%)$ and 9 females $(60 \%)$ in group (A) while it was 8 males $(53.3 \%)$ and 7 females $(46.7 \%)$ and in group (C) it was 7 males $(46.7 \%)$ and 8 females $(53.3 \%)$.

\section{As regards regurge test pre-operative:}

In group (A) there was 8 cases $(53.3 \%)$ with negative regurge test and 7 cases $(46.7 \%)$ were regurge test positive, while in group (B) there was 10 cases $(66.7 \%)$ with regurge test negative and 5 cases with regurge test positive $(33.3 \%)$ and in group (C) there was 13 cases $(86.7 \%)$ with regurge negative and only two cases $(13.3 \%)$ with regurge test positive. In average. There was $68.89 \%$ negative regurge test and $31.11 \%$ were positive.

\section{As regards the outcome:}

At the end of our study the results post operative was:

\section{1- Syringing test post operative:}

It was found that in group (A) there were success rate in 14 cases $(93.3 \%)$, in group (B) it was the same in 14 cases $(93.3 \%)$ while in group (C) it was 13 cases $(86.67 \%)$ with one case only showed obstruction in group (A) and (B) and 2 cases in group (C).

As regards the FDDT it was found to be prolonged in all patients pre-operative with average time about 7 minutes.

\section{2- As regards the fistula opening:}

The fistula was found to be opened in 14 cases $(93.33 \%)$ in group (A) and (B) while in group (C) it was open in 13 cases $(86.67 \%)$ it was closed in only one case in group (A) and (B) and in two cases in group $(\mathrm{C})$.

\section{As regards the FDDT post operative:}

It was found to be normal in 14 cases $(93.33 \%)$ in group (A) and (B) while it was normal in 13 cases $(86.67 \%)$ in group $(\mathrm{C})$ as it was prolonged in one case $(6.67 \%)$ in group (A) and (B) while it is prolonged in two cases $(13.33 \%)$ in group (C).

At the final follow-up of the patients of the three groups of patients after 6 months there were 4 cases have persistant epiphora post operative one case in group (A), one case in group (B) and two cases in group (C). These indicates that there is no significant difference between the use of intubation or not in cases of acquired NLDO and chronic dacryosistitis.

The cause of failure was found to be obstruction of the osteotomy after the follow-up period for 6 months.

Table (1): Showing age distribution of the three operated groups.

\begin{tabular}{lcclllr}
\hline \multirow{2}{*}{ Groups } & \multicolumn{2}{c}{ Age } & & \multicolumn{2}{c}{ ANOVA } \\
\cline { 2 - 3 } \cline { 5 - 6 } & Range & Mean \pm SD & & F & $p$-value \\
\hline Group A & $20-65$ & $44.000 \pm 12.851$ & & 0.232 & 0.794 \\
Group B & $30-59$ & $43.600 \pm 10.091$ & & \\
Group C & $17-53$ & $41.333 \pm 11.598$ & & \\
\hline
\end{tabular}

Table (2): Showing sex ditribution of the 45 cases operated.

\begin{tabular}{|c|c|c|c|c|c|c|c|c|c|c|}
\hline \multirow{3}{*}{ Sex } & \multicolumn{8}{|c|}{ Groups } & & \\
\hline & \multicolumn{2}{|c|}{ Group A } & \multicolumn{2}{|c|}{ Group B } & \multicolumn{2}{|c|}{ Group C } & \multicolumn{2}{|c|}{ Total } & \multicolumn{2}{|c|}{ Chi-Square } \\
\hline & $\mathrm{N}$ & $\%$ & $\mathrm{~N}$ & $\%$ & $\mathrm{~N}$ & $\%$ & $\mathrm{~N}$ & $\%$ & $X^{2}$ & $p$-value \\
\hline Male & 6 & 40.00 & 8 & 53.33 & 7 & 46.67 & 21 & 46.67 & 0.536 & 0.765 \\
\hline Female & 9 & 60.00 & 7 & 46.67 & 8 & 53.33 & 24 & 53.33 & & \\
\hline Total & 15 & 100.00 & 15 & 100.00 & 15 & 100.00 & 45 & 100.00 & & \\
\hline
\end{tabular}

Table (3): Showing results of regurge test pre-operative in the three groups.

\begin{tabular}{|c|c|c|c|c|c|c|c|c|c|c|}
\hline \multirow{3}{*}{$\begin{array}{l}\text { Regurge } \\
\text { test Pre }\end{array}$} & \multicolumn{8}{|c|}{ Groups } & \multirow{2}{*}{\multicolumn{2}{|c|}{ Chi-Square }} \\
\hline & \multicolumn{2}{|c|}{ Group A } & \multicolumn{2}{|c|}{ Group B } & \multicolumn{2}{|c|}{ Group C } & \multicolumn{2}{|c|}{ Total } & & \\
\hline & $\mathrm{N}$ & $\%$ & $\mathrm{~N}$ & $\%$ & $\mathrm{~N}$ & $\%$ & $\mathrm{~N}$ & $\%$ & $X^{2}$ & $p$-value \\
\hline Negative & 8 & 53.33 & 10 & 66.67 & 13 & 86.67 & 31 & 68.89 & 3.940 & 0.139 \\
\hline Positive & 7 & 46.67 & 5 & 33.33 & 2 & 13.33 & 14 & 31.11 & & \\
\hline Total & 15 & 100.00 & 15 & 100.00 & 15 & 100.00 & 45 & 100.00 & & \\
\hline
\end{tabular}


Table (4): Showing results of syringing test post-operative.

\begin{tabular}{|c|c|c|c|c|c|c|c|c|c|c|}
\hline \multirow{3}{*}{ Syringing } & \multicolumn{8}{|c|}{ Groups } & \multirow{2}{*}{\multicolumn{2}{|c|}{ Chi-Square }} \\
\hline & \multicolumn{2}{|c|}{ Group A } & \multicolumn{2}{|c|}{ Group B } & \multicolumn{2}{|c|}{ Group C } & \multicolumn{2}{|r|}{ Total } & & \\
\hline & $\mathrm{N}$ & $\%$ & $\mathrm{~N}$ & $\%$ & $\mathrm{~N}$ & $\%$ & $\mathrm{~N}$ & $0 / 0$ & $X^{2}$ & $p$-value \\
\hline Patent & 14 & 93.33 & 14 & 93.33 & 13 & 86.67 & 41 & 91.11 & 0.549 & 0.760 \\
\hline Obstructed & 1 & 6.67 & 1 & 6.67 & 2 & 13.33 & 4 & 8.89 & & \\
\hline Total & 15 & 100.00 & 15 & 100.00 & 15 & 100.00 & 45 & 100.00 & & \\
\hline
\end{tabular}

Table (5): Showing the fistula opening in the three groups.

\begin{tabular}{|c|c|c|c|c|c|c|c|c|c|c|}
\hline \multirow{3}{*}{$\begin{array}{l}\text { Fistula } \\
\text { opening }\end{array}$} & \multicolumn{8}{|c|}{ Groups } & \multirow{2}{*}{\multicolumn{2}{|c|}{ Chi-Square }} \\
\hline & \multicolumn{2}{|c|}{ Group A } & \multicolumn{2}{|c|}{ Group B } & \multicolumn{2}{|c|}{ Group C } & \multicolumn{2}{|c|}{ Total } & & \\
\hline & $\mathrm{N}$ & $\%$ & $\mathrm{~N}$ & $\%$ & $\mathrm{~N}$ & $\%$ & $\mathrm{~N}$ & $\%$ & $\mathrm{X}^{2}$ & $p$-value \\
\hline Open & 14 & 93.33 & 14 & 93.33 & 13 & 86.67 & 41 & 91.11 & 0.549 & 0.760 \\
\hline Closed & 1 & 6.67 & 1 & 6.67 & 2 & 13.33 & 4 & 8.89 & & \\
\hline Total & 15 & 100.00 & 15 & 100.00 & 15 & 100.00 & 45 & 100.00 & & \\
\hline
\end{tabular}

Table (6): Showing the results of the FDDT post-operative.

\begin{tabular}{|c|c|c|c|c|c|c|c|c|c|c|}
\hline \multirow{3}{*}{$\begin{array}{l}\text { FDDT } \\
\text { post }\end{array}$} & \multicolumn{8}{|c|}{ Groups } & \multirow{2}{*}{\multicolumn{2}{|c|}{ Chi-Square }} \\
\hline & \multicolumn{2}{|c|}{ Group A } & \multicolumn{2}{|c|}{ Group B } & \multicolumn{2}{|c|}{ Group C } & \multicolumn{2}{|r|}{ Total } & & \\
\hline & $\mathrm{N}$ & $\%$ & $\mathrm{~N}$ & $\%$ & $\mathrm{~N}$ & $\%$ & $\mathrm{~N}$ & 06 & $\mathrm{X}^{2}$ & $p$-value \\
\hline Normal & 14 & 93.33 & 14 & 93.33 & 13 & 86.67 & 41 & 91.11 & 0.549 & 0.760 \\
\hline Prolonged & & 6.67 & 1 & 6.67 & 2 & 13.33 & 4 & 8.89 & & \\
\hline Total & 15 & 100.00 & 15 & 100.00 & 15 & 100.00 & 45 & 100.00 & & \\
\hline
\end{tabular}

\section{Discussion}

The external approach to DCR allows good exposure of the surgical area to accurately identify anatomical landmarks, allowing the surgeon to create a well-positioned osteotomy and formation of the mucosal anastomosis [9].

In our study there was no significant difference between the three age groups with mean age 43.6 Previous literatures reported nearly the same ages: Mud-hol R. (mean age of 45.74 years) [9,10] .

Previous studies reported that most patients were females: In 2005 Emmerich K.H. (females 61\%, males 39\%) [11], while in 2011 Erdöl H. (females $81.9 \%$, males $18.1 \%$ ) [12] and Karim R. (females $60 \%$, males $40 \%$ ) [13] while in our study they were nearly the same with 24 females $(53.3 \%)$ and 21 male $(46.7 \%)$.

Silicone tube is an inert material and encapsulation around the material is formed. There has been no consensus for using silicone tube in external DCR. Some surgeons have used it as routine $[14,15]$. They have thought that silicone tube pro- tects the passage by preventing granulation tissue formation in the site of osteotomy and anastomoses in the postoperative period. They have also thought that, it prevents common canalicular obstruction. Other surgeons have preferred it for only complicated cases like unsuccessful cases, canalicular stenosis, and in cases of insufficient flap formations [16-18]. They claimed that, silicone tube may lead to several complications including punctal erosion, corneal erosion, and pyogenic granuloma formation, beyond the cost of the material.

In 2005 Ozay et al., [17], reported that indications for silicone tube implantation in their study were small-fibrotic sac in 19 cases, unsuccessful previous DCR in 9, common canalicular stenosis in 9, intraoperative technical problems in 7 , and mucocele in 3 patients. They reported the success rate as $84 \%$ and 42 had not done intubation with success rate about $88.1 \%$.

In 1994, Walland and Rose [18] reviewed 388 DCR cases and found no significant difference in failure rates for primary or repeated surgeries among subjects with and without silicone intubation. 
There are many methods for evaluation of the success for DCR operations used in literature in this study the success of DCR was defined by:

Relief of epiphora, patent lacrimal irrigation and negative flurocsien disappearance test, ENT endoscopic evaluation of nasal mucosa and patency of the fistula for follow up period up to 6 months.

All patients were followed up 1 day, 1 week, 1 month, 3 months and 6 months post-operative.

In our study we divided the patients into three groups randomly:

$\operatorname{Group}(A): 15$ patient had DCR operation with long term intubation (12 weeks) the success rate was found to be $99.33 \%$ of the patients with failure of only one case who complains of persistant epiphora post-operative with prolonged FDDT.

Group $(B)$ : 15 patient had DCR operation with short term intubation ( 2 weeks) the success rate was found to be $93.33 \%$ of the patients with failure of only one case.

Group $(C)$ : 15 patient had DCR with no intubation the success rate was found to be $86.66 \%$ of the patients with failure of two cases.

No tube related complications were recorded.

In 2012 Silicone tubes have been especially used in cases with canalicular problems. Buttanri et al., [19], used silicone tube in 69 patients with distal/common canalicular obstructions in external DCR surgery and reported the success rate as $76 \%$. They implicated that silicone tubeshould be used in patients with distal or common canalicular obstructions. In their study, although most of the patients relieved after the removal of the tubes, epiphora was started again in $21 \%$ of the patients.

In 2007 Choung et al., [20] claimed that, the silicone tube should not be used nearly half of the cases. They operated 166 cases and implanted silicone tube in 74 patients whoose both lacrimal sacs and nasal spaces were large for tear drainage. They reported that, although all pasaages were anatomically patent, epiphora was seen in $6.7 \%$.

Althought in 2007 Bazzazi et al., [21] in a randomized clinical trial study was done on 80 patients with nasolacrimal duct obstruction. These were divided into two groups of EX.DCR with and without silicone intubation incidentally. They found that the overall success rate was $77.5 \%$ in EX.DCR and $90 \%$ in EX.DCR with silicone intubation $(p<0.05)$ with more success rate in the group of EX.DCR with intubation more than group without intubtion.
In 2007 Ozkaya et al., [22], used silicone tube in nearly half of the patients and reported that the success rates were $87.5 \%$ in silicone used group, and $86.3 \%$ in silicone free group.

In 2009 in another study, Bayhan et al., [23], reported that they used silicone tube only in cases of distal/common canalicular stenoses, and smallfibrotic sacs.

In 2009 Madge and Selva [24], also reported the same conclusion that silicone tube was not required in uncomplicated cases.

In 2009 Comparative studies in this era are rare. Saiju et al., [25] studied in 100 patients and used silicone tube in 44 patients and not used in 56 patients. After six month follow-up, the success rates were $90 \%$ in silicone group, and $87 \%$ in silicone free group, and the difference between the groups was insignificant. They also reported that silicone rod increased the cost of the surgery as $20 \%$.

In 2009, Kaçaniku, [9] performed external DCR with silicone tube implantation in 41 out of 166 patients, and reported that the success rate was higher in the group with intubation $(95.1 \%)$ compared to in the group without intubation $(87.5 \%)$, but the difference was statistically insignificant. He proposed further prospective studies to confirm the beneficial effect of silicone intubation

In 2014, the same author studied in 106 patients and he used silicone tube only in 11 eleven patients who had common canalicular obstruction [26].

Recently, in 2014 a randomized clinical trial on the outcomes of external DCR with and without silastic intubation in 100 patients with uncomplicated primary Nasolacrimal Duct Obstruction (NLDO) showed that the six-month subjective and anatomic success rates were not significantly different be-tween the intubated and non-intubated groups (90\% versus $87 \%$ respectively) [27].

\section{References}

1- CAMARA JORGE G.: Nasolacrimal Duct Obstruction, emedicine (medli), 1-13, 2002.

2- BABAR T.F, MASUD M.Z, SAEED N., et al.: An Analysis of Patients with Chronic Dacryocystitis. Pak. J. Opthalmol., 19: 77-83, 2003.

3- TARBET K.J. and CUSTER P.L.: External Dacryocystorhinostomy. Surgical success, patient satisfaction, and economic cost. Opthalmology, 102: 1065-70, 1995.

4- WARREN J.F., SEIFF S.R., KAVANAGH M.C., et al.: Long-term Results of External Dacryocystorhinostomy. Opthalmic surg Lasers Imaging, 36: 446-50, 2005. 
5- SUNG EUN KIM, SUNG JUN LEE, SANG YEUL LEE and JIN SOOK YOON: Clinical significance of microbial growth on the surfaces of silicone tubes removed from dacryocystorhinostomy patients. Am. J. Ophthalmol., 153: 253-257, 2012.

6- KONUK O., KURTULMUSOGLU M., KNATOVA Z. and UNAL M.: Unsuccessful Lacrimal Surgery: Causative factors and results of surgical management in a tertiary referral center. Opthalmologica, 224: 361-366, 2010.

7- CIFTCI F., ERŞANLI D., CIVELEK L., et al.: Histopathologic changes in the lacrimal sac of dacryocystorhinostomy patients with and without silicone intubation. Ophthal. Plast. Reconstr. Surg., 21: 59-64, 2005.

8- HEINDL L.M., JUNEMANN A. and HOLBACH L.M.: A clinicopathologic study of nasal mucosa in 350 patients with external dacryocystorhinostomy. Orbit. 28: 7-11, 2009.

9- KACANIKU G. and SPAHIU K.: The Success Rate of External Dacryocystorhinostomy. Med. Arh., 63 (5): 28890, 2009.

10- EMMERICH K.H., BUSSE H. and Meyer-Rusenberg H.W.: External Dacryocystorhinostomy: Indications, method, complications and results. Orbit., Vol. 16, No. 1, Pages, 25-9, 1997.

11- ERDOL H., AKYOL N. and IMAMOGLU H.I.: Longterm follow-up of external dacryocystorhinostomy and the factors affecting its success. Orbit. Jun., 24 (2): 99102,2005

12- KARIM R., GHABRIAL R. and LYNCHT.: A comparison of external and endoscopic endonasal dacryocystorhinostomy for acquired nasolacrimal duct obstruction." Clinical ophthalmology (Auckland, NZ), 5 : 979, 2011.

13- SODHI P.K., PANDEY R.M. and MALIK K.P.: Experience with bicanalicular intubation of the lacrimal drainage apparatus combined with conventional external dacryocystorhinostomy. J. Craniomaxillofac. Surg., 31 (3): 18790, 2003.

14- VIEIRA G.S. and XAVIER M.E.: Results and complications of bicanalicular intubation in external dacryocystorhinostomy. Arq. Bras. Oftalmol., 71 (4): 529-33, 2008.

15- COBAN D.T., BEDEN U., SONMEZ B. and ERKAN D.: Outcomes of external dacryocystorhinostomy and effects of the incision type on cosmetic and functional outcomes. J. Clin. Anal. Med., 2 (1): 21-4, 2011.
16- ANDERSON R.L. and EDWARDS J.J.: Indications, complications and results with silicone stents. Ophthalmology, 86 (8): 1474-87, 1979.

17- OZAY S, BAKBAK B, ONDER F.: Silicone tube indications, external dacryocystorhinostomy. MN. Oftalmoloji., 12: 152-5, 2005.

18- WALLAND M.J. and ROSE J.E.: The effect of silicone intubation on failure and infection rates after dacryocystorhinostomy. Ophthalmic. Surg., 25: 597-600, 1994.

19-BUTTANRI I.B., SERIN D., KARSLIOGLU S., AKBABA M., FAZIL K., ACAR B. and SEVIM M.S.: The outcome of silicone intubation and tube removal in external dacryocystorhinostomy patients with distal canalicular obstruction. Eur. J. Ophthalmol., 22 (6): 878-81, 2012.

20- CHOUNG H.K. and KHWARG S.I.: Selective Nonintubation Of a Silicone Tube in External Dacryocystorhinostomy. Acta Ophthalmol Scand 85 (3): 329-32, 2007.

21- BAZZAZI N., SAMAVATI M. and MANI KASHANI K.H.: The Success rate of external dacryocystorhinostomy with and without silicone intubation. Medical Journal of Tabriz University of Medical Sciences Vol. 29, No. 1 Spring, 2007.

22- OZKAYA A., GURCAN Z., OZUSAN S. and OZEN B.: Comparing primary external dacryocystorhinostomy operations with or without silicone tube intubation. Turkiye Klinikleri. J. Ophthalmol., 16 (2): 77-81, 2007.

23- BAYHAN S.A., RECEP Ö.F., DÜZEN B. and HASıRIPI H.: The results of external dacryocystorhinostomy operations performed with single flap and double flaps. T Oft Gaz., 38: 371-4, 2008.

24- MADGE S.N. and SELVA D.: Intubation in routine dacryocystorhinostomy: why we do what we do. Clin. Experiment. Ophthalmol., 37 (6): 620-3, 2009.

25- SAIJU R., MORSE L.J., WEINBERG D., SHRESTHA M.K. and RUIT S.: Prospective randomised comparison of external dacryocystorhinostomy with and without silicone intubation. Br. J. Ophthalmol., 93 (9): 1220-2, 2009.

26- KAÇANIKU G. and BEGOLLI I.: External dacryocystorhinostomy with and without suturing the posterior mucosal flaps. Med. Arch., 68 (1): 54-6.

27- GAUBA V.: External versus endonasal dacryocystorhinostomy in a specialized lacrimal surgery center. Saudi. J. Ophthalmol. Jan., 28 (1): 36-9, 2014. 


\section{تقييه دور أنبوبة القناة الدمعية فى عملية التوصيل الخارجى

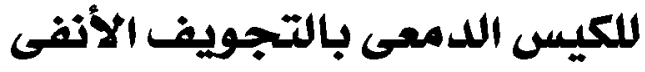

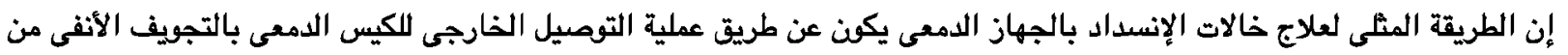

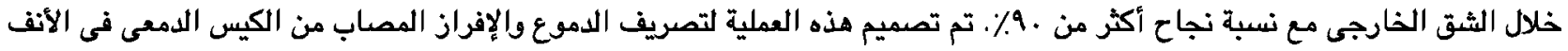

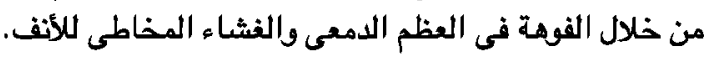

إن تنبيب الجهاز الدمعى بوضيع أنابيب السيليككن، يمثل خطوة رئيسية فى الجراحة الدمعية. لأن الأسباب الاكثر شيوعاً لفشل عملية توصيل

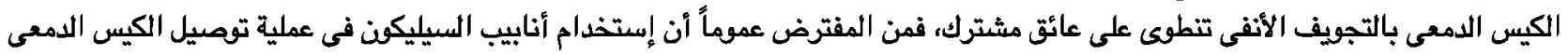

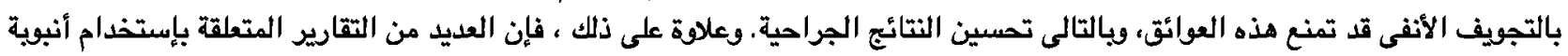

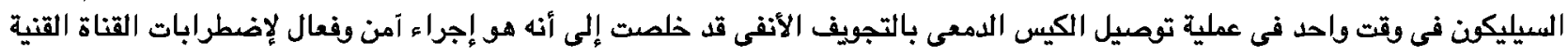
أو الأنفية الد معية.

ومع ذلك، فقد وجد أن العديد من المضاعفات تنتع عن وضع أنبوب السيليككن، وأقترع مؤخراً أن أنبوبة السيليكن خلال عملية توصيل

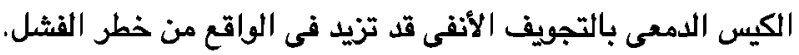

والغرض من هذه الدراسة هو تقييم دور تركيب أنبوبة قناة دمعية في نسبة نجاح عملية التوصيل الخارجى للكيس الدمعى بالتجويف الأنفى. 